\title{
Enterprise Culture: The Headspring of the Enterprise Competition Ability
}

\author{
Zhaojiang Dong \\ Shandong University (Weihai), Weihai, China \\ Email: dongzhaojiang@sdu.edu.cn
}

Received June 2013

\begin{abstract}
There are many factors that can decide and affect the enterprise competition ability. From the value chain, the article has analyzed and inquired into the formation and promotion of enterprise competition, and think that the enterprise culture is headspring of enterprise competition ability, that the product or service is the carrying of business enterprise competition ability and that the value chain is the guaranteeing of the enterprise competition ability. The enterprise culture is the headspring of nutrition to the enterprise competition ability; it is a key factor that affects the enterprise competition ability.
\end{abstract}

Keywords: Competition Ability; Enterprise Competition Ability; Enterprise Culture

\section{Introduction}

Competition is the inevitable product of the market economy and the objective law. In the fierce market competition, we must keep on to improving the enterprise competition ability in order to have an invincible position and continue to develop. The enterprise competition ability is not achieved overnight. Along with the enterprise growing up, the enterprise competition ability is also experiencing a relatively slow growth process.

\section{The Connotation of the Enterprise Competition Ability and Its Components}

Competitiveness is a very complex concept. Theory of enterprise competition ability includes interpretations from different angles and different levels. For example, the comprehensive quality of enterprise competition ability said enterprise competition ability is to point that in a competitive market, an enterprise has to keep more effective than other companies in providing products or services to the market, and gain profit and their own comprehensive quality development (Jin, 2001); Productivity said that the enterprise competition ability is a kind of productivity reflected through an enterprise selling its products in the market (Zhang, 1999); Then the management ability said that, the management ability, enterprise competition ability is the ability to be successfully engaged in business activities of the enterprise and entrepreneurs in adapting, coordinating and managing the external environment (Yan \& Zheng, 1998); Resource allocation said is that the core of enterprise competition ability is enterprise resource configuration ( $\mathrm{Li}, 2001$ ); Also some scholars use multiple indexes to define and evaluate the enterprise competition ability (Wang, 2002). The author believes that the enterprise competition ability is a three-dimensional, dynamic concept.

First of all, enterprise competition ability is a three-dimensional concept.

Enterprise competition ability seems to be a flying bullet.
The bullet that can fly far, depends on both the bullet forcethe power of the ammunition, and the bullet itself quality-texture and resistance; Based upon the quality of the launcher, and the size of the medium resistance. For businesses, the most fundamental measure for the intensity of its competition ability, is the profitability of the enterprise; And the discretion of the enterprise profitability is reflected that the enterprise is better than its competitors for providing customers with competitive products or services. Products and services competition is face to face direct competition between businesses, embodied in price competition, product competition, quality competition, service competition, etc.; Behind the competition is capital, production equipment, management and associated "logistics support" competition, which is the technology competition, talent competition, the management of the competition. And all this competition can be regarded as an industrial engineer strategy competition. Entrepreneurs are not only the first focus of the competition, but also the decision makers and commanders of the competition.

Second, enterprise competition ability is a dynamic concept.

In 1985, "World Economy Forum" in the report about the competitiveness points that in the current and future, competition ability is the ability and opportunities to design, product and sale goods with more attractive price and quality than domestic and foreign competitors in their own environment (Zhang, 1999). Evaluation of enterprise competition ability depends on the strength of the current, and needs to consider the status of the enterprise's future development even more. An enterprise in a certain period is likely to be the leader of the industry or a product in the price, new product development, marketing channels and promotion, etc., playing a leading role for other enterprise in this industry; However, it may be a market follower in the future competition with product, technology and marketing competition at a disadvantage. Then, it just imitates or follows the market leader. So, the enterprise competition ability must be examined dynamically (Bian, 2012).

Third, the measure of enterprise competition ability is constantly changing. 
People of different age, to the competitive advantage with the enterprise also have different opinions. Before the 1950s, the third industrial revolution in the past, a firm's competitive advantage even more depends on enterprise resources, especially natural resources; After World War II, with the petrochemical, electronics, aviation and other industries and mass production as a symbol of the coming of the fourth industrial revolution, technology and management are considered to be one of the enterprise competition important weights; Since the 90s, along with the United States of "information superhighway" construction as the sign, the world has entered the information age. Entering the 21st century, information technology has become an important part of enterprise competition ability (Liu, 2008).

According to the above analyses, the enterprises competition ability can be divided into three fundamental levels: the outer layer is the carrier of enterprise competition ability, embodied in the product or service competition, which is the most direct power contrast for enterprise competition; The middle is the enterprise competitiveness "processing workshop", embodied in the enterprise's resources and its configuration ability; The inner layer is the core of enterprise competition ability, embodied in comprehensive quality of entrepreneurs, such as decision-making ability, organization and coordination ability, innovation ability, interpersonal ability, etc. Entrepreneur's quality, through the enterprise culture constructed, affects the enterprise competition ability to be cultivated and enhanced. Anyhow, description of the enterprises competition ability must be three-dimensional, dynamic, and must consider how to cultivate and promote enterprise's competitiveness from the lasting competitiveness of enterprises.

\section{Nurture and Grow of the Enterprises Competition Ability}

- Enterprises have to undergo from scratch, since the childhood of the change process. The enterprise competition ability is not innate, but also to experience the process from weak to strong. Revealing the forming process of enterprise competition ability has important significance to cultivate and promote enterprise competition ability.

- American strategists Porter argued that: "The competitive advantage in the final analysis depends on it that the company can create value for customers (Kotter, 1999).” From the perspective of economics, the value enterprises create for customers is equal to the consumers' benefits (satisfaction) that acquire from company provided products deduct paid by consumers for the product cost. The much higher enterprise creating customer's value is, the more obvious competitive advantage becomes in the market. Then, we must continuously improve product quality and reduce product cost, in order to improve the cost performance of existing products and bring more value to consumers. However, consumer-related products or services competition is only a form of enterprise competitiveness. There are many competitive advantages of enterprises, such as technical superiority, talent advantage, management advantage, innovation advantage, etc. To identify the enterprise competition ability we must take enterprise activity decomposition, by looking at the activity itself and its relationship to determine the enterprise competitive advantage. To reveal and determine the enterprise competitive advantage, and find out the ways to enhance enterprise competition ability, Por- ter proposed the value chain analysis.

- Value activities are enterprises engaged in the material and technical boundaries distinct activities. There are two broad categories of value activities, namely main activities and ancillary support activities. The main activities include resource inputs, production operations, product output, marketing and after-sales service; the ancillary activities include research and development, procurement, logistics, human resources management and so on. From a competitive perspective, company competitiveness in the value chain of each link is affecting the overall enterprise competition ability.

- In the process of the cultivation and development about the enterprise competition ability, entrepreneurship plays a key role. Entrepreneurs are the focus of enterprises and initially chose the nature of the enterprise, investment direction, etc., and also ultimately decide the development direction and development of the enterprise scale. Entrepreneurs are bred the enterprise competition ability, who integrate all kinds of resources in together to form a unique competitive ability. Entrepreneur's comprehensive quality is the most primitive elements of the enterprise competition ability, and the enterprise's core competitiveness. Entrepreneurial decision determines the configuration of enterprise resources, and once the decision is wrong, it will lead to a serious decline in enterprise competition ability. But the enterprise's core competitiveness, after all, is the internal. Core competitiveness of the enterprise only through the enterprise value chain, would be converted into enterprise's concrete competitiveness. The enterprise competition ability depends not only on how well each department, and how the coordination between different departments, but also on the coordination between enterprise and the external market.

- On the basis of the theory of value chain, to a great extent, we can reveal enterprise competition ability cultivation and growth process. Entrepreneur starting a business is like a seed to be buried in the ground. The choice of seeds decides enterprise future development condition. At the same time, the quality of the land, climate, management and so on, are also the important factors that affect seed development and growth. In the long run, enterprise's success or failure depends on the strength of its own competitiveness, and the most decisive factor in enterprise competitiveness is the enterprise core ability or core competitiveness, namely the entrepreneur's comprehensive quality. Outstanding entrepreneur by building enterprise culture, carry out its management concept into the enterprise management and development of the whole process and infiltrate into various parts of the enterprise value chain and link, which produce a profound effect to the enterprise long-term survival and development.

\section{Corporate Culture and Its Determinants}

Pula Bernhard and Hammer, Michigan Business School professor, who will compare the enterprise to a tree, think that a company is like a tree; the trunk and main branch are the core product; branch is the business unit; leaves, flowers and fruit are the final products; to provide nutrients, sustain life, and solid tree root is the core competitive ability ( $\mathrm{Xu}, 2002)$. So, what provides the big tree's nutrition? The author believes that, the enterprise culture is the nutrient source for enterprise com- 
petition ability to be cultivated and improved.

The so-called enterprise culture is the enterprise in a certain ethnic culture traditions gradually formed with a sum of basic idea about the enterprise characteristics, values, moral norms, rules and regulations, lifestyle, cultural environment and suitable ways of thinking and patterns of behavior. Enterprise culture can be divided into four levels in the structure, the spiritual and cultural level, system culture level, behavior culture and material culture level.

Each company has its own unique culture of its own business philosophy and principles, their way of problem solving and decision making, and the staff behavior patterns, etc. From the form, the enterprise culture belongs to the category of ideology concept, the person's value idea. This kind of value concept and social ethics belong to the same category, and same kind of intrinsic constraint, in people's mind and concept of self-discipline. From the content, enterprise culture, the value concept, that reflecting corporate behavior and the enterprise's practical operation process, is the system arrangement and the strategic choice of the enterprise reflecting on a person's value idea. From the nature, the value concept of enterprise culture is put into practice. Enterprise culture is the value concept, that both belong to embrace and advocate, and belong to value concept be put into practice. Enterprise culture is the most fundamental factor for constraining employee behavior and the operation process. Thus, in terms of function, the value concept of enterprise culture belongs to standardize enterprise behavior, playing a fundamental role in specification to the enterprise behavior and staff behavior. The value concept of enterprise culture is the real solution to the problem, not the surface symbol used for packaging enterprise in order to look good.

Enterprise culture plays a very important role in enterprise development. Enterprise culture is the soul of the enterprise. The value concept of enterprise culture is actually the guidance for enterprise and its employees, embodied in the consciousness of each employee. Enterprise culture advocated by enterprise is a request to people with the value concept in the system arrangement and operation strategy choice. Enterprise culture is the important ideological guarantee for the enterprise system and management strategy, and also the ideal foundation for the enterprise system innovation and management of strategic innovation.

\section{Corporate Culture's Influence on the Enterprise Competition Ability}

Enterprise culture is put forward from the Japanese miracle of economic development, caused the US-Japan comparative management research boom. In the 1980s, western management scholars had a kind of new management ideas. Then, the focus of the enterprise management research began to run by the enterprise's economic factors to non-economic factors and focused on the effects of culture on management. "The enterprise culture to enterprise long-term business performance has a significant role"; "the enterprise culture in the next 10 years is likely to be key factors determine the rise and fall of the enterprise" (Kotter \& Heskett, 1997). The competitiveness of the enterprise culture to enterprise's cultivation and promotion has important influence.

Enterprise culture is an enterprise's characteristic different from other enterprises'. The values of all the enterprise members will infiltrate the enterprise daily production and operation activities, affect the normal work behavior of all employees, work attitude, spirit and business performance, etc., which can be inflected through the enterprise final product or service, and ultimately determines the enterprise's market competitiveness. Forecasters say that culture is tomorrow's economy. To further promote the development of enterprises and to truly become the world first-class enterprise, enterprise must resort to the cultural strength.

Enterprise culture is not spontaneously formed, but built by shaping. Enterprise culture influence on enterprise competition activity through the following several aspects:

First, the institutionalization of enterprise culture. The socalled institutionalization of enterprise culture, in the reality it contains two meanings: the first layer of meaning is to point that, enterprise culture is embodied in the institutional arrangement and strategic choice. While enterprise culture is reflecting the enterprise system arrangement and strategic choice through the value concept of people, we need to see the active function of culture, namely the enterprise culture having a guiding role to enterprise operation; Another layer of meaning of enterprise culture points that, enterprise culture as a value concept advocated by enterprise managers, should be gradually institutionalized to command staff's thought, and in turn affects employee and enterprise behavior.

Second, the internalization of enterprise culture. Only becoming a part of the staff values, enterprise culture can impact on employee behavior lasting. The value concept, that is committed by the enterprise and must be practiced, is infiltrated to the employees' minds by the way of instilling. Enterprise culture management can't take immediate method. That, from the entrepreneur's idea (subjective consciousness) into the concept of enterprise employees, should be through a long-term practice process. Entrepreneurs' contribution to the society is not only establishing the enterprise, producing products or services, guarantying the market supplies, but more important is created the excellent enterprise core concept, accumulated the rich knowledge of business operation, which make the enterprise become a powerful vitality of the organism with a soul, and then make the enterprise keep the lasting competitiveness. Culture can only be achieved through a long time to the specification role and control function for people. Short time assault, make movement way and hard promotion approach, can only be counterproductive. What it is important is penetrating the enterprise management idea into the hearts of employees. Enterprise culture management need to achieve spring constant blowing and moistens everything silently.

Third, the practice of enterprise culture. Enterprise culture is not just a corporate advocacy and espoused value concept, but also must be put into practice. Enterprise culture comes from practice and guides practice at the same time, which is fully implemented into practice. Thus, the value concept of enterprise culture is more than advocated. In the Haier Group, the rationality and human are combined together organically. Under the strict specification system, Haier fully absorb the management philosophy, encourage personal value pursuit, and put the enterprise culture into part of the employees' daily work, which make employees feel a kind of pressure everywhere and the have the desire to do better, and then consciously norm and constraint on their behavior.

Excellent entrepreneurs are often at the forefront in the enterprise culture construction. Chuanzhi Liu has attached great importance to Lenovo's enterprise culture construction. Leno- 
vo's culture include: speak contribution and benefit of values; into the international market of the common ideals; solidarity and coordinated operations of the overall sense; truth-seeking spirit and entrepreneurial spirit of the company; high technology enterprise social image. Although Lenovo culture embodies in enterprise strategic strength is not enough, its comprehensiveness is worth learning. Similar like Rongchang Group President advocating the enterprise culture (autonomy, self-discipline, initiative, encourage each other and confidence), Ruimin Zhang, the Haier President, proposes the enterprise culture as "people-oriented, de-centered, honestly, the gentleman debate, the polite", which has its place desired.

The quality of enterprise operators or managers decides the rise and fall of enterprises. A lot of practices at home and abroad proved repeatedly, every successful enterprise has an entrepreneur as the core of high-quality management group to support. The hugely successful enterprise is always linked with an entrepreneur's name; the entrepreneur is the soul of the enterprise success. Enterprise core competition ability, namely entrepreneur's comprehensive quality and ability, in addition to the correct decision of the entrepreneurs and enterprises tangible value chain into the concrete competitiveness of the enterprise, the other important way is shaping the unique enterprise culture, which influences each employee's sense of competition and competitive ability, and thus fundamentally improving enterprise overall competitiveness.

\section{REFERENCES}

Bian X.-K., \& Qiu W.-X. (2012). Comparative advantage and enterprises competition ability. Enterprise Economic, 3.

Jin, B. (2001). On the nature of the competitiveness of enterprises. Chinese Industrial Economy.

Kotter, J. P., \& Heskett, J. L., Zeng, Z. Translation (1997). Enterprise culture and performance. Beijing: Huaxia Publishing House.

Kotter, J. P., Mei, R.-H. Translation (1999). Marketing management. Shanghai: Shanghai People's Publishing House.

Li, G.-Y. (2001). Enterprise resource allocation power and competitiveness. Monthly Theory, 11, 88.

Liu, P. (2008). Enterprise core competition ability and cultivation in our country. Modern Economy, 1.

Wang, B.-A. (2002). Enterprise competition ability evaluation index system design. Industrial Technology \& Economy, 2, 35.

$\mathrm{Xu}, \mathrm{F}$. (2002). On state-owned foreign trade enterprise's core competition ability. International Economics and Trade Research, 1, 59.

Yan, M., \& Zheng, L.-Y. (1998). Enterprise competitiveness evaluation. Financial Theory and Practice, 4, 35.

Zhang, Z.-Q., \& Wu, J.-Z. (1999). Enterprise competitiveness and its evaluation. Management Modernization, 1, 24. 